\title{
Alliance Entrepreneurship and Entrepreneurial Orientation: The Mediating Effect of Knowledge Transfer
}

\author{
Arash Rezazadeh* and Mahsa Mahjoub
}

Faculty of Entrepreneurship, University of Tehran, Iran

\begin{abstract}
Today's rapidly changing business environment has impelled companies to cooperate with their competitors in order to gain more competitive advantages through a win-win situation. Thereby, building alliances is one of the cooperative strategies that have been adopted by many enterprises, consequently attracting great attention from scholars. However, the literature about alliances seems to lack studies in the domain of entrepreneurship. Accordingly, this paper aims to extend entrepreneurship into the field of alliances by highlighting two phenomenal concepts: alliance entrepreneurship, and entrepreneurial orientation. Hence, the relationship between these two constructs, together with the mediating role of knowledge transfer between alliance partners, is investigated. Employing the Partial Least Squares Structural Equation Modeling (PLS-SEM) technique we analyze a set of data from the automotive industry and its sub-sectors. The results confirm the significant positive effect of alliance entrepreneurship on partners' entrepreneurial orientation, as well as the mediating effect of knowledge transfer.
\end{abstract}

\begin{abstract}
Abstrak: Perubahan lingkungan bisnis masa kini telah mendorong perusahaan untuk bekerja sama dengan kompetitor agar mendapatkan keunggulan kompetitif melalui situasi menang-menang. Pengembangan aliansi menjadi salah satu strategi kerja sama yang telah diadopsi oleh banyak perusabaan yang berimplikasi menarik perhatian para ilmuwan. Namun, literatur mengenai aliansi dalam bidang kewirausabaan masib minim. Penelitian ini bertujuan untuk. memperluas kewirausahaan ke dalam bidang aliansi dengan menyoroti dua konsep fenomenal: kewirausahaan aliansi, dan orientasi kewirausahaan. Hubungan antara kedua konstruk yang dimediasi dengan transferpengetabuan antar para mitra aliansi diuji. Penelitian ini menggunakan teknik. Partial Least Squares Structural Equation Modeling (PLS-SEM) untuk. menganalisis data industri otomotif dan beberapa sub-sektornya sebagai sampel. Hasil penelitian menunjukekan adanya pengarub positif signifikan kewirausahaan aliansi, para mitra terbadap orientasi kewirausahaan, serta pengarub pemediasian transferpengetabuan.
\end{abstract}

Keywords: alliances; coopetition; entrepreneurial orientation; knowledge transfer

JEL classification: L100, L140, L260

* Corresponding author's e-mail: a.rezazadeh@ut.ac.ir 


\section{Introduction}

Entrepreneurship, as a key concept in strategic management, has attracted a great deal of attention from scholars thus far. In fact, the contribution of this phenomenon, in both theory and practice, has convinced many governments to facilitate conditions in order to bolster entrepreneurship. In this regard, entrepreneurship can be found in many disciplines, including international businesses (Dimitratos et al. 2012), social entrepreneurship (Ney et al. 2014), human resources' management (Medcof and Song 2013), and education and training (Oluwafemi et al. 2014). Furthermore, alliances are studied through various perspectives and theories, including the transaction cost theory (Willamson 1985; Kogut 1988), the resourcebased view (Eisenhardt and Schoonhoven 1996; Das and Teng 2000), network relationships' perspective (Gimeno 2004; Koka and Prescott 2008), and several other theories. However, studies of alliances in the domain of entrepreneurship have not been so frequent, thus highlighting the importance of new concepts, such as alliance entrepreneurship, which we concentrate on in this study. Since there are few studies in the entrepreneurship literature focusing on the cooperative practices between firms, especially in the form of alliances, this study attempts to expand the entrepreneurship literature into the domain of alliances, by introducing the new phenomenon of 'alliance entrepreneurship.' Filling this gap in the literature, the current research aims to elaborate on the factors relating to entrepreneurial alliances.

Despite the advent of the entrepreneurship construct, many relating concepts have been developing thus far. Entrepreneurial Orientation (EO), as one of the most fre- quently mentioned topics, has been followed by scholars and practitioners (e.g., Covin and Miller 2014; Lumpkin and Dess 1996; Wiklund and Shepherd 2003). Regarding the importance of the introduced dimensions of this concept, including innovativeness, risktaking, and pro-activeness, much research has recently involved $\mathrm{EO}$ in studies into various domains. However, alliance literature seems to lack a suitable amount of studies covering the multifarious aspects of EO during the formation of alliances. Hence this research intends to fill this gap in the literature, linking EO and its dimensions to the alliance formation factors.

In addition, a review of the alliance literature reveals that studies of this strategy are apparently lacking, from the viewpoint of the alliance formation's phases. Although a few scholars e.g. (Nielsen 2007; Cummings and Holmberg 2012) have pointed out the pre- and post-alliance formation factors for alliances, those studies have focused on strategic alliances. This implies that investigating alliances in the realm of entrepreneurship also needs to be extended to cover major preand post-alliance formation factors. Thus, while addressing this gap in the research literature, we find no evidence of studies into alliance entrepreneurship from the viewpoint of pre- and post-alliance formation factors. Thereby, one of the objectives of this study is to broaden the existing alliance entrepreneurship literature by filling the gap by identifying the pre- and post-alliance formation factors.

Furthermore, knowledge transfer, as a critical factor in collective agreements between enterprises, has been widely mentioned; highlighting the importance of sharing the knowledge and skills between partners in collaborative practices. However, 
since the entrepreneurial situation of an enterprise is crucial to an alliance's success (Marino et al. 2002; Li et al. 2011), there are few studies in the alliance literature dealing with attempts to cover the entrepreneurial orientation area by considering the knowledge transfer concept. Hereupon, bridging this gap in the research, this study aims to develop a framework including three constructs: alliance entrepreneurship, entrepreneurial orientation, and knowledge transfer, together with their relationships.

\section{Literature Review and Hypothesis Development}

\section{Alliances}

The underlying concept of coopetition, which means the simultaneous cooperation and competition between business competitors, has encouraged scholars and practitioners to study various types of joint projects. An alliance, as one of the most important types of joint ventures, refers to a long- or short-term cooperative relationship between two or more enterprises in the hope of mutually achieving their goals (Ji and Huang 2010). Through alliances, firms can gain more competitive advantages through sharing their resources. Despite the risks and other obstacles, the highly competitive current business environment drives firms to collaborate with their competitors in order to gain more benefits. Accordingly, alliances can help enterprises to survive and grow sufficiently in the current rapidly-changing environment.

There have been various types of alliances introduced by some scholars. Equity versus non-equity alliances is one of the categorizations, and has been mentioned in many studies. In line with Das and Teng (2000), where equity alliances include equity joint ventures and minority equity alliances, nonequity alliances refers to all the other contractual arrangements that do not involve equity exchange. Sampson's (2007) portfolios categorized different types of alliances, including alliances for $\mathrm{R} \& \mathrm{D}$, manufacturing, and marketing. Reviewing the alliance literature, Teng and Das (2008) stated there were three main types, namely: Joint ventures (separately incorporated entities jointly owned by partners), minority equity alliances (the acquisition of equity shares by either one or more partner firms), and contractual alliances (an agreement with no equity transaction or the creation of a new entity).

According to many scholars, strategic alliances, as one of the main types of alliance agreements, are defined as inter-firm collaborative activities aimed at fulfilling mutual strategic objectives (Das and Teng 2000). In more detail, Alani and Essam (2013) define strategic alliances as separate organizations which co-operate in order to share administrative authority, make social links and accept joint ownership.

\section{Alliance Entrepreneurship}

Studying entrepreneurship in the realm of coopetition between enterprises has presented new phenomena, such as collaborative entrepreneurship (Ribeiro-Soriano and Urbano 2009) or symbiotic entrepreneurship (Dana et al. 2008). These concepts do not focus on one specific type of cooperation between firms. It seems to be beneficial to study collective entrepreneurial practices with a focus on the type of agreements. In this regard, alliance entrepreneurship is proposed to highlight the alliance agreements between firms from the view point of entrepreneurship. 
According to Sarkar et al. (2001) alliance entrepreneurship's roots can be found in the social network perspectives pertaining to structural holes, or disconnects, in the social networks of firms that bring in entrepreneurial opportunities. An alliance agreement is recognized as an embedding strategy providing firms with the strategic capabilities to withstand constraints imposed by their network of relationships (Burt 1992). Accordingly, enterprises that can explore and exploit these entrepreneurial opportunities, by forming alliances, are more likely to obtain advantageous results. Moreover, Khalid and Larimo (2012) define alliance entrepreneurship, from the viewpoint of entrepreneurial competence, as an entrepreneurial practice resulting in the proactive formation of strategic tie-ups with partners to acquire strategic assets through these inter-firm relationships.

To build our definition of alliance entrepreneurship, we consider alliances from the perspective of entrepreneurial orientation. Thus, alliance entrepreneurship is an entrepreneurial collective activity which aims to improve the partners' entrepreneurial status in terms of their innovativeness, risk-taking, and pro-activeness. In fact, an alliance entrepreneurship determines the factors relating to the fulfillment of entrepreneurship's promises, through building alliances. From this view, alliance partners do need an evaluation of their entrepreneurial performance during and after the formation of an alliance. That is why, in our conceptualization of alliance entrepreneurship, we use the two phases of an alliance's formation, i.e., the pre-alliance and post-alliance phases (Nielsen 2007; Jennings et al. 2000) as the dimensions describing this construct. Correspondingly, the pre-alliance formation's factors include: Partners' similarities (the extent of the likeness of the partner companies, in terms of their marketing, production, raw materials, accounting, information systems, organizational structure, technology, customers, corporate culture, goals and strategies, leadership styles and human resources management practices); prior experience (the history of cooperation between the parties, in the form of alliances, being a customer, supplier, or distributer); the partners' reputation (deriving from factors such as well-known managers, high quality products/services, financial status, good relationship with other organizations and the size of the organization), and risk reduction (reduction of the possibility of loss or failure of the parties). Also, the post-alliance formation's factors are recognized as: Goals' achievement (the extent to which the partners achieve their objectives), partners' satisfaction (the extent to which the partners are happy with the outputs of the cooperation), commitment to continue the cooperation (enthusiasm and responsibility for the success of the alliance), and trust (partners' commitment to protect each other's intellectual capital).

A review of the prior scholarship reveals the potential relationships between pre- and post-alliance formations' factors. Saxton (1997), for instance, establishes the positive effects of partners' reputations, prior experience, shared decision making, and partners' similarities on alliance outcomes. Identifying the antecedents and consequences of trust in strategic alliances, Jennings et al. (2000) proposes the assumption that partners in alliances, with higher degrees of honesty and integrity, good partner reputations, and communication's openness, are more likely to trust each other. Further, pre- and postalliance formations' factors are recognized as being connected indirectly through several mediating variables. Smith and Barclay (1997), for example, confirm the positive re- 
lationship between partners' reputations and mutual satisfaction through positive mutual perceived judgment.

\section{Entrepreneurial Orientation}

In today's changing world, the word entrepreneurship is the key to coming up with this rapid change. The early literature on strategy contains many different definitions for entrepreneurship. Knight (1997) defines entrepreneurship as the pursuit of creative or novel solutions to challenges confronting a firm, including the development or enhancement of products and services, as well as new administrative techniques and technologies for performing organizational functions. Lumpkin and Dess (1996) define entrepreneurship as a new entry, this new entry means that, what entrepreneurship consists of, and the term entrepreneurial orientation, describe how this new entry is undertaken. In other words, the term 'entrepreneurial orientation' has been used to refer to the strategy-making processes and styles of firms that engage in entrepreneurial activities (Lumpkin and Dess 2001).

Indeed entrepreneurship answers this principal question: "What business shall we enter?" The answer to this question determines a firm's domain, and guides its product-market relationships and resource deployments (Lumpkin and Dess 1996). As the field of strategic management developed, however, the emphasis shifted to entrepreneurial processes, that is, the methods, practices, and decision-making styles managers use to act entrepreneurially. Five dimensions: innovativeness, risk taking, pro-activeness, autonomy, and competitive aggressiveness, have been introduced for characterizing and distinguishing key entrepreneurial processes, that is, firms' entrepreneurial orientations.
Nevertheless, the first three dimensions i.e. innovativeness, risk-taking, and pro-activeness are the more common ones for studying a firm's entrepreneurial orientation. Hence, in the current research, in line with some previous studies on entrepreneurial orientation (e.g., Covin and Slevin 1989; Miller 1983), autonomy and competitive aggressiveness are excluded from the conceptual model, firstly in order to narrow the conceptualization, and in consequence obtain more precise and detailed results. Additionally, similar to a number of prior studies (e.g., Marino et al. 2002; Naldi et al. 2007), our operationalization of entrepreneurial orientation puts more weight on these three dimensions, in order to better justify the theoretical basis supporting the relationships between the constructs.

Innovativeness, as the first dimension, refers to firms' desires to improve innovation and creativity by introducing new products/ services, as well as pursuing technological leadership and R\&D in developing new processes (Lumpkin and Dess 2001). Risk-taking is the degree to which managers are willing to invest in entrepreneurial initiatives and engage in large and risky practices that, on the one hand, may bring in advantageous results, and on the other may cause serious damage to them (Wang 2008; Van Doorn et al. 2013). The third dimension of entrepreneurial orientation is pro-activeness which pertains to firms' efforts to grasp new opportunities through predicting the future markets' needs, enabling them to act as first-movers against their competitors (Dess and Lumpkin 2005).

\section{Knowledge/Technology Transfer}

In order to have a better understanding about the term knowledge transfer, it is necessary to know what exactly the word knowl- 
edge means. Knowledge refers to an individual's personal stock of information, skills, experiences, beliefs, and memories (Alexander et al. 1991). In the context of an organization, knowledge refers to the general knowledge about customers, products, services, processes, systems, and competitors, as the main components of the enterprise's value chain (Popadiuk and Choo 2006). Based on this definition, knowledge transfer can be defined as knowledge communicated from one agent to another, such as from one individual to another, or from a group to an entire organization, in a process that may cross national borders (Buckley et al. 2005). Within the organization, knowledge transfer can be defined as the process through which the members influence each other by the knowledge exchanged through teams, units, or organizational projects (Van Wijk et al. 2008). This transfer or exchange can happen between units within a firm (internal transfer) or between different firms (external transfer) (BouLlusar and Segarra-Ciprés 2006).

It is worthwhile here to distinguish between knowledge and technology transfer, especially regarding the alliance strategy which is the main focus of our research, as it has been studied separately by either focusing on knowledge transfer or technology transfer. Following this logic, during the measurement procedure phase of this study, specific items are applied to measure each of the two variables. Technology transfer, in fact, is a type of knowledge transfer which considers technology to be a stock that brings organizations new knowledge/information. Accordingly, technology transfer refers to the dissemination of know-how through absorption and diffusion processes of 'new-to-thefirm' technologies that were developed in one organization and then applied in another organization for another purpose (Bellais and
Guichard 2006; Cui et al. 2006). There have been various studies carried out conceptualizing and operationalizing technology transfers, however, the current research adopts the indicators from Kotabe et al. (2003) in terms of sharing high-level engineering capabilities and technologies, technical support from the partners in dealing with their technological issues, and the willingness to transfer the technology.

\section{Alliance Entrepreneurship and Entrepreneurial Orientation}

As mentioned before, alliance entrepreneurship is an entrepreneurial collaborative agreement contributing to partners' entrepreneurial performance enhancements in terms of their innovativeness, risk-taking, and proactiveness. Indeed, an alliance is an entrepreneurial activity by its nature. According to Sarkar et al. (2001), there is a linkage between one dimension of entrepreneurial orientation, pro-activeness, and firms' market performance. This claim indicates that proactive alliance partners are more likely to enhance their market performance compared to the others. Furthermore, in line with Khalid and Larimo (2012), the fulfillment of entrepreneurship promises through alliances improves the partners' performance. Alliance entrepreneurship and entrepreneurial orientation linkages can be tracked down by the main shared concept they overlap, i.e., entrepreneurship. Firms engage in alliance entrepreneurship to improve their entrepreneurial performance through collaboration. Thus, the main objective of alliance entrepreneurship practices is entrepreneurship's improvement. Similarly, entrepreneurial orientation pertains to organizations' orientations towards entrepreneurial behaviors (innovation, risk-taking, and proactiveness) through specific decision-making styles, procedures, and techniques leading to 
new entries occasionally (Chow 2006). Moreover, the potential linkages between entrepreneurial orientation and performance are highlighted in many scholarly publications (e.g., Lumpkin and Dess 1996; Sarkar et al. 2001). This interconnection does exist in both stable and dynamic environments, and also high or low access to the financial capital of firms. However the direct relationship is more conclusive in stable environments, yet low access to financial resources (Wiklund and Shepherd 2005), means that in those conditions, any improvements in firms' entrepreneurial orientation is more likely to positively influence their performance.

In addition to the above, Marino et al. (2002) verify the hypothesis that SMEs (Small and Medium-sized Enterprises) with strong capabilities for innovativeness, risk-taking, and pro-activeness are more conducive to building strategic alliances. They assert that SMEs can develop their strategic alliances strategies to: Bolster their innovative performance; safeguard against unnecessary and potentially destructive risks; and seize opportunities in the market environment before their competitors can. These facts guided us to hypothesize:

\section{Hypothesis 1: Alliance entrepreneurship has a posi- tive influence on firms' entrepreneur- ial orientation.}

\section{Alliance Entrepreneurship and Knowledge Transfer}

Alliance entrepreneurship is the proactive formation of strategic networks, enabling firms to develop access relationships to acquire strategic assets. The notion of alliance entrepreneurship can be extend to the terms 'alliance capability' and 'alliance performance' in the foreign markets. Alliance capability is defined as the combination of the elements that affect alliance knowledge sharing and the skills to manage alliances. Alliance performance is considered to be the degree of accomplishment of a foreign firm's goals in a strategic alliance. In the post- alliance phase, a firm's alliance entrepreneurship is positively associated with the alliance's capability and performance in the foreign market (Khalid and Larimo 2012).

The current alliance literature can be examined on the basis of inter-firm and intra-firm antecedents to alliances and firms' performance. The intra-firm perspective examines the firm-specific processes of alliance knowledge's acquisition and specifically focuses on analyzing how alliance knowledge is transformed into alliance capability and influences alliance performance (Jörgensen et al. 2011). In the proactive formation of inter-firm relationships, entrepreneurial firms specifically target developing symmetry between the alliance process and organizational knowledge's acquirement, in order to better share the knowledge, technology, and skills (Khalid and Larimo 2012). Thus, knowledge acquirement through alliance formation can be considered as a practical strategy for entrepreneurial firms to gain competitive advantages.

The linkages between alliance entrepreneurship and knowledge transfer can also be detected with a detailed focus on the pre- and post-alliance formation factors. Alliance partners that are more similar to each other, or have prior alliance experiences, have more ideas worth sharing. In fact, when two parties have the same issues, problems, challenges, and experiences, their required knowledge would be the same, and hence they can assist each other through knowledge transfers. In this regard, Gomes-Casseres et al. (2006) validate the positive effects of similarities between alliance partners (in terms of 
technological, geographic, and business similarities) on the flow of knowledge between the allies. According to their findings, the knowledge flow between alliance pairs is facilitated in cases where they are more close to each other (similar technology, same geographic region, and same industry). Partners' reputations can also promote the transfer of knowledge between parties. The supporting evidence for the role of partners' reputations (e.g., Nielsen 2003) implies the effect of trust, so that trust is more likely to flourish when the partners have good reputations. In consequence, the knowledge can be transferred more effectively when the partners trust each other to protect their shared information. Finally, risk reduction, as one of the pre-alliance formation's factors, can contribute to the transfer of knowledge between partners. Firms tend to admit to knowledge transfers in case they intend to reduce the risks, relative to their future projects. Supporting this assumption, Das and Teng (2001) refer to the inability of partner firms to effectively learn through knowledge transfers as one of the factors determining performance risk.

Factors relating to the phase after the formation of an alliance can affect further knowledge transfers as well. Accordingly, firms that have achieved their objectives through their alliances, are more willing to share knowledge in order to help their partners reach their goals too. Similarly, the satisfied alliance partners deal with the knowledge transfer issues more easily. Besides, the partners who are more committed to cooperation, tend to be more agreeable to knowledge transfer activities, mainly because this way they can prove their responsibility for continuing the collaboration. Finally, as mentioned before, partners who trust each other are more likely to convey their ideas and findings. Therefore, based on the justifications pre- sented above, we hypothesize:

\section{Hypothesis 2: Alliance entrepreneurship has a posi- tive influence on firms' knowledge transform process.}

\section{Knowledge Transfer and Entrepreneurial Orientation}

There are few studies discussing the relationship between knowledge transfer and entrepreneurial orientation. However, it is noteworthy to refer to the process of knowledge creation, which, based on parts of some previous studies, is achieved through socialization, externalization, combination, and internalization (Li 2009). Socialization provides people with the ability to acquire knowledge through interactions, such as brainstorming by attending formal meetings. In particular, within organizations, human resources can share their experiences of functioning through externalization and contribute to the knowledge creation and development. From the resource based perspective of the firm, and viewing employees as valuable resources, organizations should provide a supportive atmosphere in which personnel can easily transfer knowledge, in order to be able to embrace intrapreneurship (entrepreneurship within existing organizations) via practices such as new product development (Agarwal et al. 2010; Li et al. 2009).

Regarding its nature of being tacit and immobile, knowledge is not easily transferred and shared. Knowledge creation through team interactions inside organizations allows managers to feel confident of engaging in risktaking behavior (Nonaka et al. 2000). Since the firms' entrepreneurial orientation involves the strategy-making processes and encourages entrepreneurial activities, applying these attitudes and behaviors are useful for companies in transforming and facilitating the utili- 
zation of new and existing knowledge to discover market opportunities. When companies develop and formulate an entrepreneurial orientation, they feel required to gain more knowledge, information and new ideas. Developing this entrepreneurial orientation, firms can develop their unique capabilities to create, transform and share the knowledge ( $\mathrm{Li}$ et al. 2009).

Knowledge/technology transfer and entrepreneurial orientation's interconnection can also be explained from the focus of the corresponding dimensions. Technology transfer through networking strategies is recognized as one of the major determinants of innovation in $\mathrm{R} \& \mathrm{D}$ joint practices (Love and Roper 1999). As a point of fact, in most cases, setting up new risky projects requires specialized knowledge/technology which can be difficult and demanding for firms to acquire individually. Competitive advantages gained from knowledge transfer activities can drive firms' engagement in risk-taking as the managers feel more empowered by newly acquired capabilities. In particular, in the case of internationalization (Easterby Smith et al. 2008) and entering the globalized markets or export commitments, corporations need a sufficient understanding of the local factors, in terms of culture, policies, and the like. Over and above that, pro-activeness is highly relied on to gain the first-hand knowledge required for exploring and exploiting new opportunities in the markets. To be the first one able to seize an opportunity, prior to any rivals, requires having unique and valuable knowledge/information about the market. Thereby, knowledge transfer can provide firms with advantageous competencies reinforcing their entrepreneurial orientation; then we can reasonably expect to find the positive relationship between entrepreneurial orientation and knowledge's transformation process. In this regard, we hypothesize:

Hypothesis 3: Alliance partners' knowledge transfers positively influence their entrepreneurial orientation.

Figure 1. Research Conceptual Model

H1 (+)

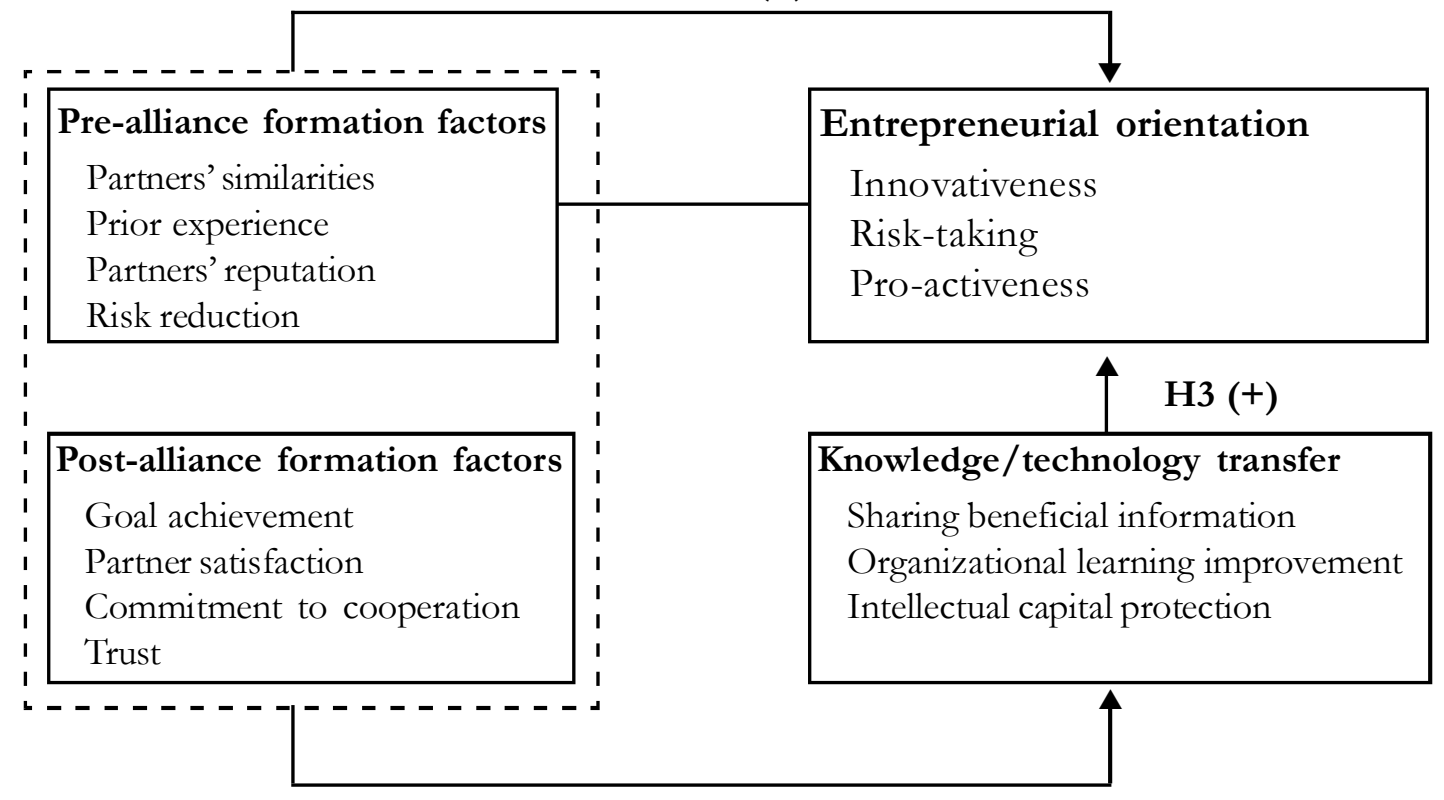

H2 (+) 


\section{Conceptual Model}

According to our hypotheses derived from the literature review, the research's conceptual model was drawn as shown in Figure 1. Based on this framework, the main focus on this study is on the investigation of the direct effect of alliance entrepreneurship on entrepreneurial orientation, as well as the indirect effect of alliance entrepreneurship on entrepreneurial orientation through the mediating construct of knowledge transfer.

\section{Methods}

According to research hypotheses which deal with confirming the relationships between constructs, this research is of the confirmatory type. Furthermore, the proposed research methodology for this study is quantitative. Accordingly, questionnaires were designed in order to test the hypotheses and understand the relationships between the constructs. This helped to empirically test the fitness of our conceptual model.

\section{Sample}

We located the sample from Iranian automobile manufacturing-related companies who have formed alliances, as they are more appropriate for this research than other types of companies. The automotive industry is recognized as one of the industries with the greatest potential for forming alliances, and therefore companies in this sector, either in automobile manufacturing itself or in the production of auto-parts, undertake various types of collaborations such as alliances, $R \& D$ joint ventures, mergers/acquisitions, or buyer/supplier relationships. We chose the automobile industry and its sub-sectors because forming alliances is common in this industry. Alliances between giant companies such as Renault-Nissan in 1999, Ford-Mazda in the 1970s, Chrysler-Fiat in 2009, BMWToyota in 2012, and Peugeot-GM, also in 2012, are all cases representing the strong desire of automobile manufacturers to engage in alliances.

The sampling technique in this research was purposive and judgmental. Accordingly, all the individuals working in the selected alliance partner companies were chosen to fill in the questionnaires. The priority was for persons who were more involved with joint practices between the parties. Also, we preferred upper or top management members, as we found them more knowledgeable about their companies' crucial operations. Therefore, a non-probability sampling technique was used.

Due to the number of the study's population which was rather large, we located a sample as the limitations of the research, in terms of time and charges, handicapped the survey process. In particular, using Cochran's formula (Cochran 1954) and also Krejcie and Morgan's table (Krejcie and Morgan 1970) we chose 116 experts working in alliance partner companies as our sample size. Regarding these rules of thumb, in the case of an unknown population size, with an error amount of 0.091 (a confidence level of $9 \%$ ), $z=1.96$, and $\mathrm{p}=\mathrm{q}=0.5$, the sample size would be 116. Taking into account that at least 116 people should be considered as the sample size, we tried to choose experts from key departments in the selected firms, including strategic management, HRM, finance, marketing, $R \& D$, and the top senior management committees. A priority was given to higher level managers and executives since the decisions for engaging in alliances are generally made at these levels. However, in some cases, lower-ranking managers and the line executives were also included in the sample, in or- 
der to gather a broader span of information from different view points. After the distribution of the questionnaires, a total of 109 completed questionnaires were collected and used for our data analysis.

\section{Measures}

This study's measurement instrument contains three sections, each with items related to the three main constructs i.e. alliance entrepreneurship, entrepreneurial orientation, and knowledge transfer. The items were adapted from the most relevant literature, as well as the most cited publications.

The first section contains eight items for measuring alliance entrepreneurship under two dimensions: The pre-alliance formation factors and post-alliance formation factors. The pre-alliance formation factors' construct was measured via four items including: Similarities between alliance partners, prior experience between them, partners' reputation, and risk reduction. These items were adapted from Saxton (1997), Arend (2009), Nielsen (2007), and Das and Teng (2000). Post-alliance formation's factors were measured by four items: The goal's achievement through the alliance, partners' satisfaction from building the alliance, commitment of the parties to cooperate after the formation of the alliance, and finally the extent of trust between the partners. These items were adapted from Bengtsson and Kock (1999) and Gulati (1998).

The second section of our measurement tool entails ten items measuring three dimensions of entrepreneurial orientation, namely innovativeness (three items), risk-taking (three items), and pro-activeness (four items). These items were derived from Hughes and Morgan (2007) and Dess and Lumpkin (2005).
Finally, the third section of our instrument includes eight items measuring knowledge transfer (three items) and technology transfer (five items) between alliance partners. Studies undertaken by Kotabe et al. (2003) and Simonin (1999) were used for generating the items measuring knowledge and technology transfer.

\section{Results}

We used the Structural Equation Modeling with Partial Least Squares (PLS-SEM) technique for analyzing the data. Considering the proposed model in this research, which contains different constructs and relationships, applying the SEM technique proved to be beneficial as it enables the analysis of multiple relationships between latent variables. The reasons for this choice are that SEM, as a comprehensive and flexible multivariate analysis approach, has some dominant advantages such as the estimation of latent variables, measurement error accounting, precise assessment of the structural relationships between variables, and in general, testing complex hypothesized models with sufficient methods. Specifically, we applied the Partial Least Squares (PLS) approach, due to its capabilities in calculating models with small sample sizes, non-normal data, and also ensuring convergence. A Smart PLS 2.0 software package was employed for conducting the modeling process and testing the respective hypotheses of the study. The procedure of analyzing the data through the PLS approach were implemented in two sections of the measurement model and the structural model, so that in each section a series of techniques and criteria were applied to analyze the data more accurately. In the following sections, these two phases are described. 


\section{Measurement Model Assessment}

We evaluated the fitness of our measurement models through a reliability and validity assessment. In this regard, reliability, as the consistency of measurement, helps to identify the accuracy and precision of the items (observed variables) which are used for measuring a latent variable. For assessing reliability, we used three criteria including factor loadings, Cronbach's alpha, and Composite Reliability (CR). In this regard, we first checked the factor loadings between the latent variables and their respective indicators. According to (Hulland 1999), loadings should be higher than 0.4 for adequate item reliability. Our results showed that three items (one from the pre-alliance formation factors, one from innovativeness, and one from pro-activeness) had loadings lower than 0.4. Therefore, we exclude them from our model and ran the model without them. The new results showed that all the items had greater loadings than 0.4 , confirming the sufficient item reliability of our model. In addition to the factor loadings, internal consistency was evaluated via calculating two criteria i.e. Cronbach's alpha values and Composite Reliability (CR). Cronbach's alpha and CR values of greater than the cutoff value of 0.7
(Fornell and Larcker 1981) imply the acceptable internal consistency. However, Moss et al. (1998) suggested that an alpha score of 0.6 is generally acceptable for constructs with a small number of items. The initial running of our model pointed to low amounts of CR and alpha for the pre-alliance formation factor's construct. So, we applied the 'scaleif-item-deleted' command in SPSS in order to identify the item which decreased the alpha i.e. question number 6 . After deleting this item, the results turned out to be appropriate for all the first-order constructs as shown in Table 1, indicating sufficient internal consistency.

In addition to internal consistency, construct validation, in terms of the convergent and discriminant validity, was used to assess the adequacy of our measurement models more accurately. Accordingly, convergent validity concerns the adequacy of items in explaining each latent variable by checking the criterion of the Average Variance Extracted (AVE) values. In line with Fornell and Bookstein (1982), AVEs for each construct should be used to address the convergent validity. AVEs should be above the threshold of 0.5 (Hulland 1999) which represents an adequate level of convergent validity.

Table 1. Internal Consistency and Convergent Validity Assessment

\begin{tabular}{lcccc}
\hline First-order latent variables & No. of items & CR & Cronbach's alpha & AVE \\
\hline Pre-alliance formation factors & 3 & 0.83 & 0.70 & 0.63 \\
Post-alliance formation factors & 4 & 0.81 & 0.66 & 0.59 \\
Innovativeness & 2 & 0.86 & 0.68 & 0.76 \\
Risk-taking & 3 & 0.86 & 0.77 & 0.69 \\
Pro-activeness & 3 & 0.84 & 0.73 & 0.65 \\
Knowledge transfer & 3 & 0.87 & 0.78 & 0.69 \\
Technology transfer & 8 & 0.84 & 0.77 & 0.52 \\
\hline
\end{tabular}


Table 2. Discriminant Validity Assessment

\begin{tabular}{lccccccc}
\hline First-order constructs & $\mathbf{1}$ & $\mathbf{2}$ & $\mathbf{3}$ & $\mathbf{4}$ & $\mathbf{5}$ & $\mathbf{6}$ & $\mathbf{7}$ \\
\hline 1. Pre-alliance formation factors & $\mathbf{0 . 7 9}$ & & & & & & \\
2. Post-alliance formation factors & 0.41 & $\mathbf{0 . 7 6}$ & & & & & \\
3. Innovativeness & 0.29 & 0.41 & $\mathbf{0 . 8 7}$ & & & & \\
4. Risk-taking & 0.41 & 0.18 & 0.27 & $\mathbf{0 . 8 3}$ & & & \\
5. Pro-activeness & 0.33 & 0.26 & 0.31 & 0.24 & $\mathbf{0 . 8 0}$ & & \\
6. Knowledge transfer & 0.27 & 0.33 & 0.32 & 0.36 & 0.32 & $\mathbf{0 . 8 3}$ & \\
7. Technology transfer & 0.38 & 0.41 & 0.40 & 0.32 & 0.19 & 0.20 & $\mathbf{0 . 7 2}$ \\
\hline
\end{tabular}

Based on the information given in Table 1, all the AVE values of the first-order constructs were greater than 0.5 , confirming the adequate convergent validity.

Additionally, the discriminant validity considers the relationships between constructs, with careful attention to the AVE values of each construct. For assessing the discriminant validity, as recommended by Fornell and Larcker (1981), we compared the total variance shared between each first-order latent variable via the square roots of their AVEs and the correlations between constructs. For an acceptable discriminant validity, the constructs' square roots of their AVEs should be higher than the correlations between the constructs. Information given in Table 2 demonstrates the adequacy of the discriminant validity for our measurement models.

\section{Structural Model Assessment}

In this stage, we analyze the relationships between constructs (latent variables) according to the research's conceptual model. The latent variables were treated under two groups, namely the first-order and secondorder. First-order constructs were directly connected with indicators (items), whereas the second-order ones were treated as the main constructs that relate to the items through the first-order constructs. Figure 2 displays the results of running our model with Smart PLS software. According to this figure, first, it is clear that the $\mathrm{R}^{2}$ values for the first-order endogenous latent variables, which are shown inside the circles within the parentheses, are generally high, as only two constructs have $\mathrm{R}^{2}$ values of less than 0.32 , which was proposed by Chin (1998) as a moderate inner path effect. Moreover, all of the relationships between the latent variables in the model are significant at 99 percent and 99.9 percent. This implies the confirmation of the research's three hypotheses. Furthermore, the path coefficients indicate that the direct effect of Alliance Entrepreneurship (AE) on Entrepreneurial Orientation (EO) is stronger than the indirect effect through Knowledge Transfer (KT)/Technology Transfer (TT). It can be verified from the coefficient corresponding to the direct effect of $\mathrm{AE}$ on $\mathrm{EO}(0.383)$, which is higher than the coefficient representing the indirect effect through the mediating variable of KT\&TT $(0.486 * 0.233=0.113)$. The significance of the relationships between $\mathrm{AE}$ and 
Figure 2. Research Model with Path Coefficients and Significance Level

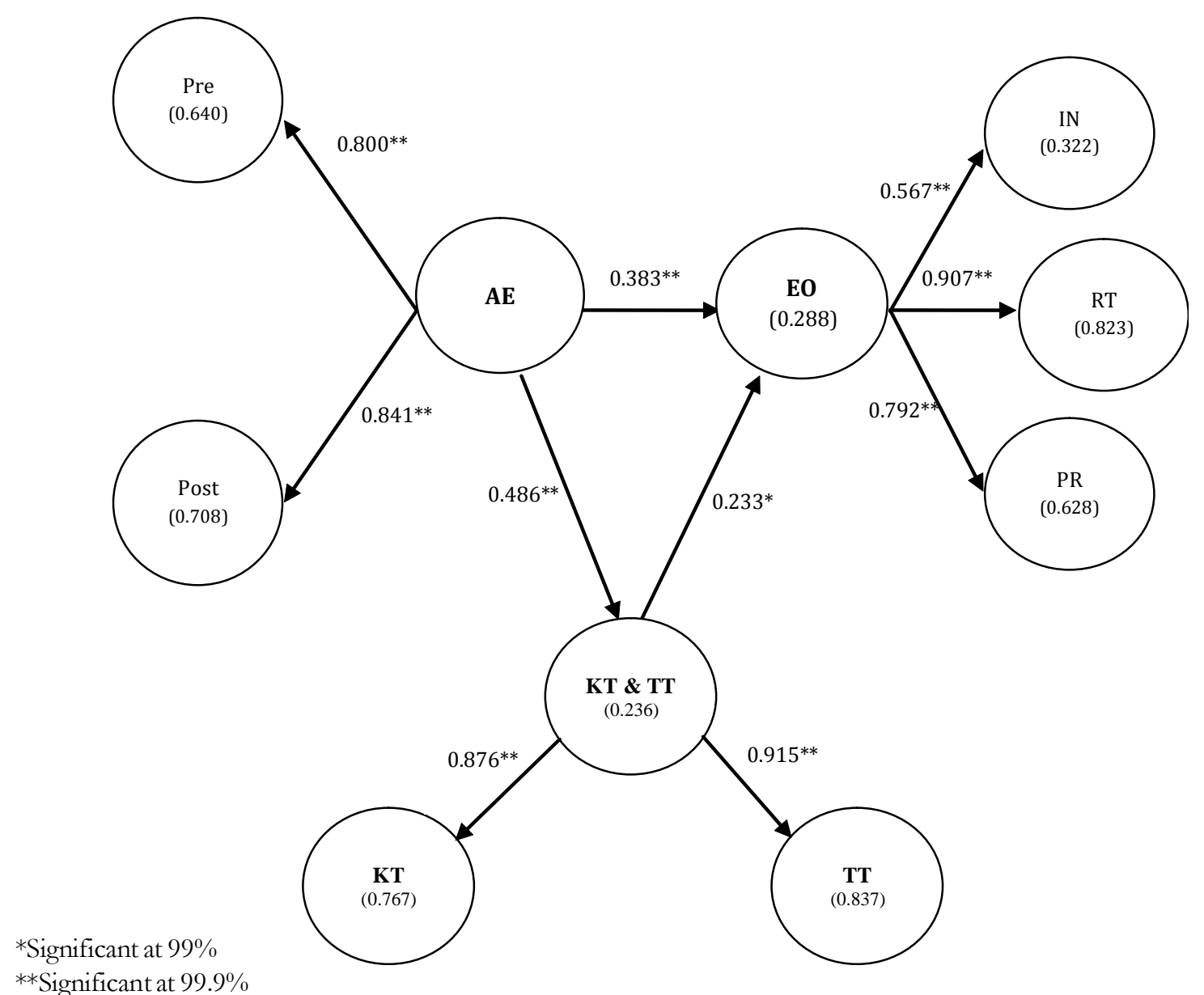

** Significant at $99.9 \%$

Notes: Pre: Pre-alliance formation factors, Post: Post-alliance formation factors, AE: Alliance Entrepreneurship, KT\&TT: Knowledge and Technology Transfer, KT: Knowledge Transfer, TT: Technology Transfer, EO: Entrepreneurial Orientation, IN: Innovativeness. RT: Risk Taking, PR: Pro-activeness.

$\mathrm{KT} / \mathrm{T} T$, and also between $\mathrm{KT} / \mathrm{T}$ 'T and $\mathrm{EO}$ establishes the consideration of $\mathrm{KT} / \mathrm{TT}$ as the mediating variable between $\mathrm{AE}$ and $\mathrm{EO}$. Especially, the rather high degree of coefficient related to the AE - KT/TT relationship (i.e., 0.486) reveals the mediating effect of KT/TT rather than any potential moderating effect.

In addition to the analysis of t-values and path coefficients, we assessed the significance of the mediating influence of the KT\&TT construct in the relationship between $\mathrm{AE}$ and EO using the Sobel test (Sobel
1982). As shown in the following formula, the $z$-value of the mediating effect in our model equals 2.229 , which is significant at 95 percent, confirming the mediating effect of knowledge-technology transfer.

$$
\begin{aligned}
Z \text {-value } & =\frac{a \times b}{\sqrt{\left(b^{2} \times s_{a}^{2}\right)+\left(a^{2} \times s_{b}^{2}\right)+\left(s_{a}^{2} \times s_{b}^{2}\right)}}= \\
& \frac{0.486 \times 0.233}{\sqrt{\left(0.233^{2} \times 0.075^{2}\right)+\left(0.486^{2} \times 0.097^{2}\right)+}}\left(\begin{array}{c}
\left(0.075^{2} \times 0.097^{2}\right) \\
\end{array}\right. \\
& =2.229
\end{aligned}
$$




\section{Discussion}

Drawing on the results of the data analysis, the first finding of this study is that alliance entrepreneurship has a significant positive effect $(p<0.001)$ on firms' entrepreneurial orientation. Sarkar et al's. (2001) findings confirm a linkage between pro-activeness, as one dimension of entrepreneurial orientation, and firms' performance. This implies that the more proactive the parties are during and after the formation of alliances, the better performance they are likely to achieve. This statement is in line with our first finding, and we assert the positive influence of alliance agreements upon parties' entrepreneurial orientation, in terms of innovativeness, risk-taking, and pro-activeness. Moreover, Khalid and Larimo's (2012) findings reveal a positive connection between alliance entrepreneurship and alliance performance, implying the beneficial outputs of alliances for firms improving their performance. In addition, Dess and Lumpkin (2005) conclude that effective corporate entrepreneurship, which may be pursued via mergers and acquisitions, as well as through joint ventures and strategic alliances, has a positive relationship with firms' entrepreneurial orientation. They emphasize that firms' strong entrepreneurial orientation, in terms of their innovativeness, risk-taking, pro-activeness, autonomy, and competitive aggressiveness, has the potential to enhance the creation and pursuit of new venture opportunities and strategic renewals.

The second finding is the demonstration of the significant positive effect of alliance entrepreneurship on knowledge transfer. This suggests that the formation of successful alliances between firms brings in beneficial knowledge and technology transfer activities between the partners. Consistent with other research, a number of scholars have pointed out the knowledge transfer process during alliances. For instance, studying inter-firm knowledge transfers within strategic alliances, Mowery et al. (1996) suggests that alliance activity can promote increased specialization through effective knowledge transfers between the partners. Furthermore, Khalid and Larimo's (2012) results confirm the moderating role of the acquisition of knowledge from an alliance on the relationship between alliance entrepreneurship and alliance capability. The combination of technological capabilities that helps partners acquire new knowledge and, in turn, compensate for their lack of specialization, are highlighted as one of the key advantages of forming alliances (Kavusan et al. 2016). There is no doubt that resource sharing is one of the most important incentives for any inter-firm collaborative activity, and transferring knowledge, as the most strategically-significant resource (Simonin 1999: 595), determines the success of the cooperation.

Another major finding of this research is that the knowledge transfer gained through alliances improves the partnering firms' entrepreneurial orientation. In fact, knowledge has been frequently referred to as an influencing factor in entrepreneurship literature. The flow of new knowledge into an organization triggers the value creation process, ending in entrepreneurial outputs such as innovative thinking and the behavior of employees (Agarwal et al. 2010). In accord with Li et al. (2011), cooperation members' entrepreneurial orientation -reflected in their innovativeness, pro-activeness and risk taking- significantly determines the knowledge acquisition from inter-relationship activities between producer and distributer. This is consistent with the literature on both entrepreneurship and knowledge management, where 
scholars agree with the effects of knowledge acquired from external sources and firm's entrepreneurial orientation (Gellynck et al. 2015). In fact, a company's management committee feels more confident taking entrepreneurial actions when it has more knowledge about the business opportunities or threads.

Our final important finding is that the transfer of knowledge between alliance parties mediates the relationship between alliance entrepreneurship and entrepreneurial orientation. This mediation effect, which is a complete mediation, according to the research conceptual model, highlights the significant effect of alliance entrepreneurship on knowledge transfer, as well as the effect of knowledge transfer on entrepreneurial orientation. Accordingly, the fulfillment of entrepreneurship through alliances provides partners with valuable knowledge of the key competitive advantages they need to improve their performance. Besides, the acquired knowledge helps them bolster their innovativeness, risktaking, and pro-activeness. It means that on the one hand, alliance entrepreneurship contributes to the effective acquirement of knowledge, and on the other, successful knowledge acquisition through alliances can enhance firms' abilities to manage inter-organizational relationships. Taking a more detailed look at the mediation effect, it can be implied that the successful implementation of certain strategies, prior to and after the alliance's formation, fortifies the partners' abilities to innovate, take more risks, and proactively seize new opportunities. In other words, if the parties share more similar features and have already experienced joint activities, and also if they enjoy a positive public image and have tried to reduce the risk of failure, it is more likely that they will effectively share beneficial information, improve organizational learning, and protect intellec- tual capital, which in turn boosts their entrepreneurial orientation. This is also true if one partner succeeds in the following duties after the formation of alliance: To help the other party achieve their own goals, to keep the other member satisfied with the cooperation available, to maintain the commitment to keep sharing resources, and finally to trust each other when using the resources and getting access to the other side's shared information.

\section{Conclusion}

Bridging the gaps in the alliance literature, the present research attempts to study alliances from the viewpoint of entrepreneurship. To do so, we developed and empirically tested a model comprising of the three main constructs and their relationships. Alliance entrepreneurship as the predictor variable, entrepreneurial orientation as the criterion variable, and knowledge transfer as the mediating variable, are the main elements of our proposed model.

There are some factors highlighting the implications for research. Firstly, the theme of cooperation and competition among organizations is a challenging issue, because firms have to compete and also engage in cooperative actions, such as alliances, to gain more benefits in the current densely competitive and rapidly changing environment. More specifically, entrepreneurship's enhancement through alliances is another challenge for alliance partners, who need to monitor their situation after forming alliances to benchmark the outcomes against other activities. In this regard, the entrepreneurial situation of partners could be a suitable criterion for measuring performance. For this purpose, inspecting the state of innovativeness, risk-taking, and pro-activeness among alliance partners 
could help them to evaluate their performance more accurately. Therefore, it was well worth entering the entrepreneurial orientation construct into our investigation.

Despite the great deal of research into the issue of alliances, there is little research in the literature that studies alliances by considering their entrepreneurship context. Thus, to bridge this gap in the research, this study attempts to extend the future alliance literature into the domain of entrepreneurship. Identifying the dimensions of the alliance's entrepreneurship construct, understanding its effect on partners' entrepreneurial orientation, as well as assessing the mediating role of knowledge transfer, the present research has tried to clarify the alliance entrepreneurship construct and develop a relevant comprehensive framework, as well as testing this model utilizing the proper techniques and approaches.

In addition to the theoretical contributions, the findings of this study, in our view, bring some important managerial implications. First and foremost, drawing on our conclusions, firms that intend to develop their entrepreneurial status can benefit not only from engaging in alliances, but also from knowledge/technology transfers. As a result, managers can evaluate the success of their alliances by examining the extent to which their company could benefit from knowledge/technology transfers. Moreover, the consideration of alliance entrepreneurship from both the pre-alliance and post-alliance formation factors could help managers separate the factors affecting their cooperative arrangements into two phases (before and after the formation of alliances), this is helpful especially for dealing with issues imposed by the alliance agreement. In this way, managers can better realize whether it is expedient to participate in an alliance or not. In simple terms, if the partner has any prior experience, similar characteristics, or a satisfactory reputation, the managers can be more confident of building an alliance. Similarly, indicators suggested as the post-alliance formation's factors could also help managers to assess the extent to which the alliance is beneficial. This way they can better decide whether to continue with, or withdraw from, the collaboration.

Finally, in this section we would like to point out some avenues for further research, mainly derived from the limitations of this research. Like any research, this study has several limitations which should be considered when undertaking future (and perhaps better) research. Firstly, our conceptual model is narrowed down to the relationships between the three constructs, namely alliance entrepreneurship, entrepreneurial orientation, and knowledge transfer. However, entering more variables as independent, mediator, dependent, or moderator factors can bring useful results. A quick literature review (Atuahene-Gima and Ko 2001; Li et al. 2009; Lumpkin and Dess 1996; Renko et al. 2009) suggests 'market orientation' or 'technological capability' as determining factors for entrepreneurial orientation; business performance as a variable affecting alliance entrepreneurship; and innovation, networking capabilities, or organizational learning as potential mediating variables in the linkage between alliance entrepreneurship and entrepreneurial orientation. Additionally, our conceptualization of alliance entrepreneurship stems from the pre- and post-alliance formations' perspective. For future research one could define and conceptualize this construct by adopting relevant theories and perspectives of management and organization. A resourcebased view of the firm, social network theory, strategic perspectives, and organizational 
learning theory could be worth of pursuit too. Finally, concerning the research methodology adopted for this research, one could gain more pragmatic results through qualitative operationalization of the constructs, as well as qualitative analysis of the relationships focused on in this study. For instance, conducting two focus group sessions (each separately, with participants from different alliance partners) could result in useful insights.

To put it in a nutshell, this study casts new light on the issue of alliance failures. We found that one major reason for alliance partners' decisions to withdraw from their collaborations is the ignorance of their entrepreneurial status during and after the formation of alliances. Accordingly, the importance of the new concept 'alliance entrepreneurship' is highlighted in this research. Accord- ing to our results, paying attention to alliance entrepreneurship's enhancement, in terms of the pre- and post-alliance formations' factors, leads to partners' entrepreneurial orientation improvements in terms of innovativeness, risk-taking, and pro-activeness. Further, our findings indicate that knowledge and technology transfers between alliance partners mediate the relationship between alliance entrepreneurship and entrepreneurial orientation. It denotes that firms can acquire knowledge from their competitors via alliances, and if they succeed in achieving this aim, their entrepreneurship's effectiveness factors including innovativeness, risk-taking, and pro-activeness are bound to be augmented.

\section{References}

Agarwal, R., D. Audretsch, and M. B. Sarkar. 2010. Knowledge spillovers and strategic entrepreneurship. Strategic Entrepreneurship Journal 4 (4): 271-283.

Alani, S., and A. Essam. 2013. Challenges and opportunities of mergers and alliances between universities. Leadership and Organization Development Journal 15 (4): 31-36.

Alexander, P. A., D. L. Schallert, and V. C. Hare. 1991. Coming to terms: How researchers in learning and literacy talk about knowledge. Review of Educational Research 61 (3): 315-343.

Arend, R. J. 2009. Reputation for cooperation: contingent benefits in alliance activity. Strategic Management Journal 30: 371-385.

Atuahene-Gima, K., and A. Ko. 2001. An empirical investigation of the effect of market orientation and entrepreneurship orientation's alignment on product innovation. Organization science 12 (1): 54-74.

Bengtsson, M., and S. Kock. 1999. Cooperation and competition in relationships between competitors in business networks. Journal of Business and Industrial Marketing 14: 178-194.

Bou-Llusar, J. C., and M. Segarra-Ciprés. 2006. Strategic knowledge transfer and its implications for competitive advantage: An integrative conceptual framework. Journal of Knowledge Management 10 (4): 100-112.

Buckley, P. J., M. J. Carter, J. Clegg, and H. Tan. 2005. Language and social knowledge in foreign-knowledge transfer to China. International Studies of Management and Organization 35 (1): 47-65.

Burt. 1992. Structural Holes. Cambridge, MA: Harvard University Press. 
Chin, W. W. 1998. The partial least squares approach to structural equation modeling. Modern Methods for Business Research: 295-336.

Chow, I. H. S. 2006. The relationship between entrepreneurial orientation and firms' performance in China. SAM Advanced Management Journal 71 (3): 11-20.

Cochran, W. G. 1954. The combination of estimates from different experiments. Biometrics 10: 101-129.

Covin, J. G., and D. P. Slevin. 1989. Strategic management of small firms in hostile and benign environments. Strategic Management Journal: 10: 75-87.

Covin, J. G., and D. Miller. 2014. International entrepreneurial orientation: Conceptual considerations, research themes, measurement issues, and future research directions. Entrepreneurship Theory and Practice 38 (1): 11-44.

Cui, A. S., D. A. Griffith, S. T. Cavusgil, and M. Dabic. 2006. The influence of market and cultural environmental factors on technology transfer between foreign MNCs and local subsidiaries: A Croatian illustration. Journal of World Business 41 (2): 100-111.

Cummings, J. L. and S. R. Holmberg. 2012. Best-fit alliance partners: The use of critical success factors in a comprehensive partner selection process. Long Range Planning 45: 136-159.

Dana, L. P., H. Etemad, and R. W. Wright. 2008. Towards a paradigm of symbiotic entrepreneurship. International Journal Entrepreneurship and Small Business 5 (2): 109-126.

Das, T. K., and B. S. Teng. 2000. A resource-based theory of strategic alliances. Journal of Management 26 (1): 31-61.

Das, T. K., and B. S. Teng. 2001. Trust, control, and risk in strategic alliances: An integrated framework. Organization Studies 22 (2): 251-283.

Dess, G. G., and G. T. Lumpkin. 2005. The role of entrepreneurial orientation in stimulating effective corporate entrepreneurship. The Academy of Management Executive 19 (1): 147-156.

Dimitratos, P., I. Voudouris, E. Plakoyiannaki, and G. Nakos. 2012. International entrepreneurial culture: Toward a comprehensive opportunity-based operationalization of international entrepreneurship. International Business Review 21 (4): 708-721.

Easterby Smith, M., M. A. Lyles, and E. W. Tsang. 2008. Inter organizational knowledge transfer: Current themes and future prospects. Journal of Management Studies 45 (4): 677-690.

Eisenhardt, K. M., and C. B. Schoonhoven. 1996. Resource-based view of strategic alliance formation: Strategic and social effects in entrepreneurial firms. Organization Science 7 (2): 136-150.

Fornell, C. and F. L. Bookstein. 1982. Two structural equation models: LISREL and PLS applied to consumer exit-voice theory. Journal of Marketing Research: 440-452.

Fornell, C. and D. F. Larcker. 1981. Evaluating structural equation models with unobservable variables and measurement error. Journal of Marketing Research: 39-50.

Gellynck, X., J. Cárdenas, Z. Pieniak, and W. Verbeke. 2015. Association between Innovative Entrepreneurial Orientation, Absorptive Capacity, and Farm Business Performance. Agribusiness 31 (1): 91 106.

Gimeno, J. 2004. Competition within and between networks: The contingent effect of competitive embeddedness on alliance formation. Academy of Management Journal 47 (6): 820-842.

Gomes-Casseres, B. J. Hagedoorn, and A. B. Jaffe. 2006. Do alliances promote knowledge flows?. Journal of Financial Economics 80 (1): 5-33. 
Gulati, R. 1998. Alliances and networks. Strategic Management Journal, 19: 293-317.

Hughes, M., and R. E. Morgan. 2007. Deconstructing the relationship between entrepreneurial orientation and business performance at the embryonic stage of firm growth. Industrial Marketing Management 36 (5): 651-661.

Hulland, J. 1999. Use of partial least squares (PLS) in strategic management research: A review of four recent studies. Strategic management journal 20: 195-204.

Jennings, D. F., K. Artz, G. L. Murray, and C. Christodouloy. 2000. Determinants of trust in global strategic alliances: AMRAD and the Australian biomedical industry. Competitiveness Review: An International Business Journal 10 (1): 25-44.

Ji, H., and Y. Huang. 2010. A Research on Influential Factors Related to the Stability of CompetitionOriented Strategic Alliances. International Journal of Business and Management 5 (11): 148.

Jörgensen, J. H., C. Bergenholtz, R. C. Goduscheit, and E. S. Rasmussen. 2011. Managing inter-firm collaboration in the fuzzy front-end: Structure as a two-edged sword. International Journal of Innovation Management 15 (01): 145-163.

Kavusan, K., N. G. Noorderhaven, and G. M. Duysters. 2016. Knowledge acquisition and complementary specialization in alliances: The impact of technological overlap and alliance experience. Research Policy 45 (10): 2153-2165.

Khalid, S., and J. Larimo. 2012. Affects of alliance entrepreneurship on common vision, alliance capability and alliance performance. International Business Review 21 (5): 891-905.

Knight, G. A. 1997. Cross-cultural reliability and validity of a scale to measure firm's entrepreneurial orientation. Journal of Business Venturing 12 (3): 213-225.

Kogut, B. 1988. Joint ventures: Theoretical and empirical perspectives. Strategic Management Journal 9 (4): 319-332.

Koka, B. R., and J. E. Prescott. 2008. Designing alliance networks: The influence of network position, environmental change, and strategy on firm performance. Strategic Management Journal 29 (6): 639661.

Kotabe, M., X. Martin, and H. Domoto. 2003. Gaining from vertical partnerships: Knowledge transfer, relationship duration, and supplier performance improvement in the US and Japanese automotive industries. Strategic Management Journal 24 (4): 293-316.

Krejcie, R. V., and D. W. Morgan. 1970. Determining sample size for research activities. Educ Psychol Meas.

Li, Y. H., J. W. Huang, and M. T. Tsai. 2009. Entrepreneurial orientation and firm performance: The role of knowledge creation process. Industrial Marketing Management 38 (4): 440-449.

Li, Y., Y. Liu, and H. Liu. 2011. Coopetition, distributor's entrepreneurial orientation and manufacturer's knowledge acquisition: Evidence from China. Journal of Operations Management 29 (1): 128-142.

Love, J. H., and S. Roper. 1999. The determinants of innovation: R\&D, technology transfer and networking effects. Review of Industrial Organization 15 (1): 43-64.

Lumpkin, G. T., and G. G. Dess. 1996. Clarifying the entrepreneurial orientation construct and linking it to performance. Academy of Management Review 21 (1): 135-172.

Lumpkin, G. T., and G. G. Dess. 2001. Linking two dimensions of entrepreneurial orientation to firm performance: The moderating role of environment and industry life cycle. Journal of Business Venturing 16 (5): 429-451. 
Marino, L., K. Strandholm, H. K. Steensma, and K. M. Weaver. 2002. The moderating effect of national culture on the relationship between entrepreneurial orientation and strategic alliance portfolio extensiveness. Entrepreneurship Theory and Practice 26 (4): 145-160.

Medcof, J. W., and L. J. Song. 2013. Exploration, exploitation and human resource management practices in cooperative and entrepreneurial HR configurations. The International Journal of Human Resource Management 24 (15): 2911-2926.

Miller, D. 1983. The correlates of entrepreneurship in three types of firms. Management Science 29: 770-791.

Moss, S., H. Prosser, H. Costello, N. Simpson, P. Patel, S. Rowe, S. Turner, and C. Hatton. 1998. Reliability and validity of the PAS ADD Checklist for detecting psychiatric disorders in adults with intellectual disability. Journal of Intellectual Disability Research 42: 173-183.

Mowery, D. C., J. E. Oxley, and B. S. Silverman. 1996. Strategic alliances and inter-firm knowledge transfer. Strategic Management Journal 17 (S2): 77-91.

Naldi, L., M. Nordqvist, K. Sjöberg, and J. Wiklund. 2007. Entrepreneurial orientation, risk taking, and performance in family firms. Family Business Review 20 (1): 33-47.

Ney, S., M. Beckmann, D. Gräbnitz, and R. Mirkovic. 2014. Social entrepreneurs and social change: tracing impacts of social entrepreneurship through ideas, structures and practices. International Journal of Entrepreneurial Venturing 6 (1): 51-68.

Nielsen, B. B. 2003. An empirical investigation of the drivers of international strategic alliance formation. European Management Journal 21 (3): 301-322.

Nielsen, B. B. 2007. Determining international strategic alliance performance: A multidimensional approach. International Business Review 16: 337-361.

Nonaka, I., R. Toyama, and N. Konno. 2000. SECI, Ba and leadership: A unified model of dynamic knowledge creation. Long Range Planning 33: 5-34.

Oluwafemi, C. O., O. R. Martins, and H. O. Adebiaye. 2014. Entrepreneurial education: Solution to unemployment and under employment. Journal of Poverty, Investment and Development 5: 69-72.

Popadiuk, S., and C. W. Choo. 2006. Innovation and knowledge creation: How are these concepts related? International Journal of Information Management 26 (4): 302-312.

Renko, M., A. Carsrud, and M. Brännback. 2009. The effect of a market orientation, entrepreneurial orientation, and technological capability on innovativeness: A study of young biotechnology ventures in the United States and in Scandinavia. Journal of Small Business Management 47 (3): 331-369.

Ribeiro-Soriano, D., and D. Urbano. 2009. Overview of collaborative entrepreneurship: An integrated approach between business decisions and negotiations. Group Decision and Negotiation 18 (5): 419430.

Sampson, R. C. 2007. R\&D alliances and firm performance: The impact of technological diversity and alliance organization on innovation. Academy of Management Journal 50 (2): 364-386.

Sarkar, M. B., R. Echambadi, and J. S. Harrison. 2001. Alliance entrepreneurship and firm market performance. Strategic Management Journal 22 (6-7): 701-711.

Saxton, T. 1997. The effects of partner and relationship characteristics on alliance outcomes. Academy of Management Journal 40: 443-461.

Simonin, B. L. 1999. Ambiguity and the process of knowledge transfer in strategic alliances. Strategic Management Journal 20: 595-623. 
Smith, J. B., and D. W. Barclay. 1997. The effects of organizational differences and trust on the effectiveness of selling partner relationships. The Journal of Marketing 61: 3-21.

Sobel, M. E. 1982. Asymptotic confidence intervals for indirect effects in structural equation models. Sociological Methodology 13: 290-312.

Teng, B. S., and T. Das. 2008. Governance structure choice in strategic alliances: The roles of alliance objectives, alliance management experience, and international partners. Management Decision 46: 725742.

Van Doorn, S., J. J. Jansen, F. A. Van den Bosch, and H. W. Volberda. 2013. Entrepreneurial orientation and firm performance: Drawing attention to the senior team. Journal of Product Innovation Management 30 (5): 821-836.

Van Wijk, R., J. J. Jansen, and M. A. Lyles. 2008. Inter and Intra Organizational Knowledge Transfer: A Meta Analytic Review and Assessment of its Antecedents and Consequences. Journal of Management Studies 45 (4): 830-853. 